\title{
BIMBINGAN TEKNIS PENGELOLAAN PERPUSTAKAAN DAN PENGADAAN MEJA LIPAT DI MADINAH MAARIF 10 MALANG
}

\author{
Winda Harsanti ${ }^{1}$, Suselo Utoyo ${ }^{2}$, Agus Suhardono ${ }^{3}$, Utami Retno P. ${ }^{4}$, Mona Shinta S. ${ }^{5}$ \\ 1,2,3,4,5 Dosen Jurusan Teknik Sipil Politeknik Negeri Malang \\ 1 winda.harsanti@polinema.ac.id, 2sslutoyo@gmail.com, 3agus.suhardono@polinema.ac.id \\ 4utami.retno@polinema.ac.id, ${ }^{5}$ monashinta2003@gmail.com
}

\begin{abstract}
Madinah Maarif 10 is one of the nonformal education that operates in the religious field in Malang. In effort to maintain the quality of education and the quantity of students, Madinah established a library and once every year learning activities are held outside the Madinah. Library management is done by Madinah manager helped by students as assistants and supervised by head master of Madinah. To support activites which is done in outside Madinah, it is needed to make small folding table from wood so that light and stay longer.
\end{abstract}

Kata kunci: folding tables, library, librarian

\section{PENDAHULUAN}

\subsection{Latar Belakang}

Pendidikan merupakan suatu bentuk pembelajaran dalam hal pengetahuan, ketrampilan, dan kebiasaan sekelompok orang yang diturunkan dari satu generasi ke generasi berikutnya. Secara umum fungsi pendidikan sendiri adalah untuk mengembangkan kemampuan dan membentuk watak, kepribadian, serta peradaban yang bermartabat pada seseorang.

Saat ini pendidikan dapat diberikan dalam beberapa cara, yaitu pendidikan formal, pendidikan non formal dan pendidikan informal. Salah satu bentuk pendidikan non formal adalah Taman Pendidikan Al-Quran atau TPA. Pendidikan TPA saat ini umum dilaksanakan bagi anak usia pendidikan dasar. Hampir di setiap daerah yang memiliki penduduk muslim terdapat TPA. Semenjak adanya kebijakan pemerintah, yaitu Peraturan Kementerian Pendidikan dan Kebudayaan No. 23 tahun 2017 tentang penerapan lima hari sekolah, berdampak pada menurunnya jumlah peserta didik di TPA. Seperti yang terjadi di daerah Lampung, dimana pada tempat tersebut terdapat 20 peserta didik, namun setelah turunnya kebijakan pemerintah tentang lima hari sekolah tidak ada peserta didik yang mengikuti pendidikan di tempat tersebut (wan/tau/jun/byu, 2017).

Madrasah Diniah Maarif 10 merupakan salah satu TPA yang berada di Kota Malang, yang saat ini masih berjalan. TPA ini sendiri berlokasi di Jl. Jaksa Agung Suprapto II/86 Malang. Saat ini TPA tersebut memiliki peserta didik kurang lebih sebanyak 60 orang. Apabila dibandingkan dengan TPA di sekitar lokasi, peserta didik yang dimiliki TPA ini cukup banyak. Untuk tetap menjaga agar peserta didik tidak berkurang, pihak pengelola melakukan berbagai upaya untuk menarik minat peserta didik agar tetap mengikuti pendidikan non formal ini. Upaya tersebut diantaranya adalah dengan membuat perpustakaan kecil di TPA yang tidak hanya berisi buku tentang keagamaan, namun juga buku yang bersifat ilmu pengetahuan umum. Upaya lainnya untuk menjaga agar jumlah peserta didik tidak berkurang adalah mengadakan kegiatan di luar TPA yang bertempat di rumah peserta didik secara bergiliran yang diadakan satu bulan penuh setiap bulan puasa.

Kendala yang saat ini dialami oleh TPA tersebut adalah adanya fasilitas perpustakaan yang saat ini belum diimbangi dengan pengelolaan yang baik, sehingga pemanfaatan buku tersebut dirasa masih sangat kurang. Selain itu pada saat pelaksanaan kegiatan di luar TPA, peserta didik belum menggunakan fasilitas yang memadahi yaitu belum adanya meja yang dapat digunakan. Hal ini disebabkan karena tidak memungkinkannya membawa fasilitas meja yang ada di TPA keluar dari TPA, yang disebabkan oleh ukuran meja yang terlalu besar sehingga menyulitkan untuk dibawa ke luar TPA.

\section{TINJAUAN PUSTAKA}

\subsection{Pendidikan}

Pendidikan adalah usaha sadar dan terencana untuk mewujudkan suasana belajar dan proses pembelajaran agar peserta didik secara aktif mengembangkan potensi dirinya untuk memiliki kekuatan spiritual keagamaan, pengendalian diri, kepribadian, kecerdasan, akhlak mulia, serta keterampilan yang diperlukan dirinya dan masyarakat. Di dalam Undang-Undang No. 20 tahun 2003 pasal 13 ayat 1 , disebutkan bahwa pendidikan dapat dilakukan melalui tiga jalur yang berbeda. Jalur tersebut diantaranya pendidikan formal, non formal dan informal.

Pendidikan formal merupakan jalur pendidikan yang terstruktur serta berjenjang dari tingkat terendah yaitu pendidikan anak usia dini sampai jenjang tertinggi yaitu universitas. Metode pendidikan dengan jalur non formal adalah pendidikan yang dilakukan di luar pendidikan formal yang dapat dilakukan secara tersturktur dan berjenjang (Meliyakin, 2013). Hasil 
dari pendidikan ini dapat disetarakan dengan pendidikan formal apabila terdapat penyetaraan nilai yang dilakukan oleh lembaga yang ditunjuk oleh pemerintah. Beberapa contoh dari pendidikan non formal diantaranya lembaga kursus, lembaga pelatihan, kelompok belajar, dan pusat kegiatan belajar masyarakat.

Pendidikan informal adalah jalur pendidikan keluarga dan lingkungan yang berbentuk kegiatan belajar secara mandiri. Berdasarkan Peraturan Pemerintah Nomor 17 tahun 2010 pasal 117 dinyatakan bahwa hasil dari pendidikan informal ini dapat dihargai setara dengan hasil pendidikan formal dan non formal setelah melalui uji kesetaraan yang memenuhi standar nasional pendidikan (Anonim, Guru Pantura, 2015).

\subsection{Perpustakaan}

Perpustakaan adalah suatu tempat untuk mengakses informasi yang bersifat ilmu pengetahuan, hiburan, rekreasi, maupun ibadah dalam bentuk cetak maupun digital. Berdasarkan Undang-Undang No. 43 tahun 2007 tentang perpustakaan, yang dimaksud dengan perpustakaan adalah institusi pengelola koleksi karya tulis, karya cetak, dan atau karya rekam secara professional dengan system yang baku untuk memenuhi kebutuhan Pendidikan, penelitian, pelestarian, informasi, dan rekreasi para pemustaka. Di dalam istilah yang lebih luas dan bersifat umum, perpustakaan mencakup suatu ruangan, bagian dari gedung atau bangunan, atau Gedung tersendiri yang berisi buku-buku koleksi yang disusun dan diatur dengan rapi dan sistematis sehingga pencarian buku dapat dilakukan dengan mudah (Mangapeng, 2016).

Dengan adanya perpustakaan diharapkan pengguna perpustakaan dapat:

1. Mendidik dirinya sendiri secara berkesinambungan

2. Tanggap dalam kemajuan pada berbagai ilmu pengetahuan, kehidupan sosial maupun politik

3. Mengembangkan kemampuan berpikir kreatif, membina rohani dan menggunakan kemampuannya untuk menghargai hasil seni dan budaya manusia

4. Meningkatkan taraf hidup

5. Menggunakan waktu senggang dengan baik yang bermanfaat bagi kehidupan pribadi dan sosial

\subsection{Kategori Perpustakaan}

Perpustakaan sendiri dapat dikategorikan menjadi lima jenis, yaitu perpusakaan umum, perpustakaan khusus, perpustakaan nasional, perpustakaan perguruan tinggi, dan perpustakaan sekolah (Kurniawan, 2011). Masing-masing dari jenis perpustakaan tersebut akan diuraikan seperti berikut ini.

1. Perpustakaan umum
Suatu perpustakaan yang diselenggarakan di suatu daerah masyarakat tertentu untuk memberikan pelayanan kepada masyarakat umum setempat termasuk dalam kategori perpustakaan umum. Contoh dari perpustakaan umum adalah perpustakaan umum propinsi, perpustakaan umum kabupaten/ kota madya, perpustakaan umum kecamatan, dan perpustakaan umum desa.

2. Perpustakaan khusus

Perpustakaan yang diselenggarakan oleh dan di suatu instansi atau lembaga khusus seperti lembaga pemerintahan, lembaga niaga atau lembaga idustri, untuk memberikan pelayanan kepada staf dari instansi atau lembaga yang bersangkutan merupakan jenis pengertian dari perpustakaan khusus.

3. Perpustakaan nasional

Perpustakaan nasional yaitu suatu perpustakaan yang diselenggarakan oleh suatu negara pada tingkat nasional yang bertugas mengumpulkan, menyimpan dan menyebarluaskan semua bahan pustaka yang pernah terbit di negara yang bersangkutan.

4. Perpustakaan perguruan tinggi

Perpustakaan yang diselenggarakan oleh perguruan tinggi untuk memberikan pelayanan kepada civitas academica perguruan tinggi bersangkutan merupakan definisi dari perpustakaan perguruan tinggi.

5. Perpustakaan sekolah

Perpustakaan sekolaj adalah perpustakaan yang diselenggarakan di sekolah untuk memberikan pelayanan kepada murid dan guru.

\subsection{Pengelolaan Perpustakaan}

Salah satu faktor yang mempengaruhi berkembang atau tidaknya suatu perpustakaan adalah cara pengelolaan perpustakaan. Di dalam pengelolaan ini diperlukan adanya staf perpustakaan yang terdiri dari pustakawan, asisten pustakawan, tenaga fungsional, dan tenaga administrasi (Mangapeng, 2016).

1. Pustakawan dengan pendidikan paling rendah Strata 1 (S1) dalam bidang Ilmu Perpustakaan, Dokumentasi dan Informasi (Pusdokinfo), atau S1 bidang studi lain yang memiliki kompetensi dalam pengelolaan perpustakaan, bertugas melaksanakan tugas keprofesian dalam bidang perpustakaan.

2. Asisten pustakawan dengan pendidikan ilmu perpustakaan tingkat diploma dalam bidang Ilmu Perpustakaan, Dokumentasi dan Informasi (Pusdokinfo) bertugas melaksanakan tugas keprofesian dalam bidang perpustakaan.

3. Tenaga fungsional lain dengan pendidikan kejuruan atau keahlian tingkat kesarjanaan dengan tugas melaksanakan pekerjaan penunjang keprofesian seperti pranata komputer dan kearsipan. 
4. Tenaga administrasi dengan tugas melaksanakan kegiatan kepegawaian, keuangan, kerumahtanggaan, perlengkapan, penjilidan, perlistrikan, grafika, dan lain-lain.

\subsection{Konsep Pelayanan Perpustakaan}

Pada umumnya perpustakaan mempunyai sistem pelayanan yang dikenal dengan sistem pelayanan terbuka dan sistem pelayanan tertutup. Sistem pelayanan terbuka (open acces system) memberikan kebebasan kepada pengunjung perpustakaan untuk memasuki ruang koleksi dan memilih sendiri koleksi yang dibutuhkan. Salah satu tujuannya adalah memperkenalkan koleksi perpustakaan kepada pengunjung agar lebih mengenal akan perpustakaan. Pada sistem layanan terbuka bisa diterapkan apabila tersedia ruangan yang cukup luas dan memungkinkan peserta didik dalam mengambil koleksi buku yang diinginkan. Jarak antara rak buku satu dengan yang lainnya cukup luas, sehingga memudahkan peserta didik dalam mencari buku yang diinginkan. Disamping itu penataan rak buku harus diatur sedemikian rupa agar pustakawan tetap bisa mengawasi sirkulasi penggunaan buku meskipun pada ruangan yang luas.

Sistem pelayanan tertutup merupakan kebalikan dari sistem pelayanan terbuka, dimana pengunjung tidak boleh memasuki ruang koleksi, tetapi memesan koleksi yang dibutuhkan lewat petugas perpustakaan. Dalam sistem tertutup ini, peserta didik tidak diijinkan untuk mengambil koleksi buku sendiri. Untuk itu perlu adanya pemisah antara wilayah yang dapat dijangkau peserta didik dan yang tidak bisa.

\subsection{Pengawasan Perpustakaan}

Pengawasan adalah kegiatan yang membandingkan atau mengukur apa yang sedang atau sudah dilaksanakan dengan kriteria, norma - norma standar atau rencana - rencana yang sudah ditetapkan sebelumnya (Kurniawan, 2011). Pengawasan dimulai sejak proses perencanaan, sampai dengan akhir suatu tahap kegiatan. Pengawasan tersebut dapat dibedakan menjadi tiga, yaitu:

1. Pengawasan langsung atasan kepada bawahan, yang sering disebut pengawasan melekat (waskat) yang pelaksanaanya dapat rutin atau berkala (periodik), dan sifatnya internal.

2. Pengawasan fungsional (wasnal), yang dilakukan oleh lembaga di luar organisasi yang sifatnya eksternal. Pengawasan tersebut dilakukan oleh suatu badan pengawas/pemeriksa dan dilakukan secara berkala ataupun sewaktu - waktu (insidental) jika diperlukan.

Pengawasan yang dilakukan oleh masyarakat (wasmas), baik melalui lembaga perwakilan (DPR), Lembaga Swadaya Masyarakat (LSM), pers, maupun perorangan. Mekanisme pelaksanaan pengawasan oleh masyarakat tersebut dapat dilakukan secara terbuka, transparan, langsung atau tidak langsung.

\subsection{Koleksi Buku}

Koleksi buku yang dapat disimpan di perpustakaan tidak hanya buku ajar saja, namun juga buku dari kategori lainnya. Koleksi tersebut dapat berupa buku penunjang, buku referensi, buku cerita sampai terbitan berkala seperti surat kabar atau majalah.

\subsection{Sistem Peminjaman Buku}

Dalam perkembangan perpustakaan, sistem peminjaman buku perpustakaan juga mengalami banyak perubahan sesuai dengan kebutuhan, situasi, dan kondisi. Beberapa sistem peminjaman yang dapat diterapkan di perpustakaan seperti Sistem Ledger, Sistem Dummy, Sistem Slip, Sistem Kartu Buku, Sistem Newark, Sistem Detroit dan Sistem Browne.

\subsection{Sistem Anggaran}

Anggaran adalah unsur utama untuk menjalankan perpustakaan, tanpa anggaran perpustakaan tidak mungkin dapat berjalan dengan sempurna meskipun sistemnya bagus dan pustakawannya bermutu. Anggaran tersebut adalah untuk membiayai agar perpustakaan tetap dapat digunakan dan semakin berkembang. Fungsi anggaran perpustakaan sendiri sebagai alat perencanaan, alat koordinasi, alat pengendalian, dan menetapkan standar kegiatan yang akan dilaksanakan. Penyediaan anggaran digunakan untuk membayar gaji pegawai, pemeliharaan bangunan, dan pengadaan barang. Sebagai alat koordinasi, penyusunan anggaran akat mengaitkan berbagai bidang, bagian, dan unit dalam satu lembaga. Sehingga, apabila terjadi ketidaksesuaian antar bidang atau unit, dapat didiskusikan untuk menemukan pemecahan permasalahan.

Salah satu tujuan pengendalian anggaran perpustakaan adalah agar sasaran yang telah ditetapkan dapat dicapai. Oleh karena itu, dengan memperhatikan anggaran dan realisasinya akan mudah diketahui jika terdapat penyelewengan. Dengan demikian akan segera diadakan peringatan dan pembetulan. Dengan anggaran yang pasti, seluruh kegiatan dalam lembaga dapat segera dilaksanakan sesuai perencanaan karena adanya jaminan biaya. Anggaran dapat disusun apabila telah memiliki program kerja. Anggaran digunakan sebagai alat untuk menjamin agar sasaran jangka pendek dan jangka panjang dapat dicapai dengan cara membandingkannya dengan realita.

\subsection{Meja}


Meja adalah sebuah mebel atau perabotan yang memiliki permukaan datar dan kaki-kaki sebagai penyangga, yang bentuk dan fungsinya bermacammacam. Salah satu bentuk meja adalah meja lipat. Meja ini berukuran kecil, sehingga mudah untuk dipindahkan. Material meja lipat saat ini sudah bervariasi, ada yang terbuat dari aluminium, baja, atau kayu. Meja lipat berbahan aluminium memiliki bobot yang ringan, memiliki daya tahan lebih baik sehingga produk meja lipat dengan bahan tersebut dapat dipakai dalam jangka waktu yang panjang. Karakteristik dari material baja adalah tahan terhadap panas namun memiliki bobot yang lebih besar dibandingkan dengan meja lipat berbahan lainnya. Material kayu merupakan alternatif bahan untuk mebeler yang memiliki tekstur alami yang karakteristiknya sangat lekat dengan alam. Material kayu yang umum digunakan seperti kayu jati, kayu mahoni, kayu pinus, multiplek, dan teakblock (Lamudi, 2014).

\section{METODE}

Metode yang digunakan dalam upaya meningkatkan pengelolaan kegiatan perpustakaan adalah:

1. Meninjau lokasi perpustakaan yang dimiliki mitra dan melihat potensi peserta didik yang dapat dilibatkan dalam pengelolaan perpustakaan

2. Membuat usulan SOP pengelolaan perpustakaan

3. Menyampaikan usulan SOP kepada mitra

4. Memperbaiki SOP apabila ada masukkan dari pengelola/ mitra

Metode untuk pembuatan meja lipat adalah:

1. Membuat desain meja lipat

2. Menyampaikan desain kepada mitra

3. Memperbaiki desain sesuai masukkan dari mitra

4. Membuat meja dengan desain yang telah disepakati

\section{HASIL DAN PEMBAHASAN}

\subsection{Pengelolaan Perpustakaan}

Pengelolaan perpustakaan madrasah diniah untuk menuju perpustakaan yang baik, perlu dilakukan pada berbagai aspek. Komponne aspek tersebut meliputi aspek pengelola, konsep pelayanan, pengawasan pelaksanaan, ragam koleksi buku, sistem peminjaman sampai penyusunan anggaran.

\subsection{Pengelolaan Perpustakaan}

Berdasarkan konsep perpustakaan yang baik, ada empat komponen pengelola dalam sebuah perpustakaan. Mulai dari pustakawan, asisten pustakawan, tenaga fungsional, dan tenaga administrasi. Di sisi lain, pada perpustakaan madrasah di mitra PkM yang tidak terlalu besar, pengelola perpustakaan yang disusulkan dapat disederhanakan menjadi pustakawan dan asisten pustakawan saja. Tugas tenaga fungsional dan tenaga administrasi dapat dirangkap oleh pustakawan atau asisten pustakawan. Hal ini dilakukan karena keterbatasan tenaga yang dimiliki, tidak terlalu banyaknya koleksi buku yang ditangani, serta pengguna perpustakaan yang tidak terlalu banyak.

Posisi pustakawan dapat dilakukan oleh tenaga pendidik dari madrasah, diutamakan yang belum memiliki jabatan tambahan pada madrasah diniah. Asisten pustakawan diusulan untuk melibatkan peserta didik yang dianggap senior dan memiliki tanggung jawab yang tinggi. Hal ini dilakukan karena selain keterbatasan tenaga pendidik yang dapat dilibatkan dalam keterbatasan pengelolaan perpustakaan, tugas dari asisten pustakawan adalah melayani peminjaman buku saja. Untuk pelaksanaan administrasi yang lebih kompleks, misalkan pencatatan koleksi buku hingga pengelolaan anggaran dilakukan oleh pustakawan.

\subsection{Konsep Pelayanan Perpustakaan}

Konsep pelayanan pada suatu perpustakaan ada dua macam, yaitu sistem pelayanan terbuka dan sistem pelayanan tertutup. Berdasarkan kondisi madrasah yang memiliki lahan yang terbatas, konsep pelayanan yang sesuai menggunakan sistem layanan tertutup. Hal ini dikarenakan dalam sistem ini tidak membutuhkan lahan yang luas. Di sisi lain, dalam sistem layanan ini tidak mendidik peserta didik untuk belajar bertanggung jawab dalam peminjaman buku dan kurang bebas dalam memilih buku yang akan dibaca. Selain itu, terbatasnya pengelola perpustakaan juga menjadi kendala dalam melaksanakan sistem ini. Berdasarkan konsep pelayanan tertutup, semua kegiatan yang berhubungan dengan pinjam-meminjam buku harus dilayani oleh pengelola perpustakaan. Untuk mengatasi permasalahan tersebut, maka konsep pelayanan yang diusulkan adalah mengombinasikan pelayanan terbuka dan pelayanan tertutup.

Dalam sistem kombinasi ini, pada area yang terbatas namun tetap memberi kebebasan pada peserta didik dalam memanfaatkan koleksi buku. Pengaturan penataan buku di rak khusus yang berukuran tidak terlalu besar dan mudah dijangkau perlu dilakukan dengan baik. Di dekat rak tersebut disediakan ruang terbuka kecil yang dapat dimanfaatkan oleh peserta didik pada saat membaca. Lokasi area membaca dengan peletakkan rak buku yang berdekatan juga akan memudahkan pustakawan dalam mengawasi penggunaan buku. Beragamnya koleksi buku yang tersedia dalam satu rak buku akan mempersulit peserta didik dalam mencari koleksi buku yang diinginkan. Untuk mempermudah pencarian buku yang diinginkan maka diperlukan katalog buku. Pengaturan dan penataan buku harus sesuai dengan petunjuk di dalam katalog. 


\subsection{Pengawasan Perpustakaan}

Pada perpustakaan madrasah diniah ini, pengawasan perpustakaan dapat dilakukan langsung oleh ketua madinah. Hal ini dikarenakan lingkup perpustakaan yang tidak terlalu besar, koleksi buku yang belum terlalu banyak, pengelola perpustakaan yang sedikit, serta dana yang dikelola juga tidak besar maka tidak diperlukan pengawas dari eksternal (luar pengelola madrasah diniah). Hal ini juga akan mempermudah koordinasi antara pengawas dengan pengelola perpustakaan.

Pengawasan terhadap tata kelola perpustakaan dapat dilakukan selama enam bulan atau satu tahun sekali. Setelah dilakukan pengawasan, jika ada hasil dari pengawasan yang kurang baik maka dapat dijadikan rencana kerja pada periode berikutnya. Pemecahan dari kekurangan pengelolaan dapat dikoordinasikan antara pengelola perpustakaan dengan pengawas, yang dalam hal ini adalah kepala madrasah.

\subsection{Koleksi Buku}

Ragam jenis koleksi buku yang dapat disimpan pada perpustakaan madrasah yang utama adalah buku yang berkaitan dengan agama, terutama yang terkait kurikulum pendidikan di madrasah. Meskipun koleksi buku yang utama adalah yang berkaitan dengan Pendidikan agama, namun tidak menutup kemungkinan jenis buku yang lain dapat dijadikan penambah koleksi. Dengan syarat, koleksi buku tersebut harus mengandung unsur mendidik dan tidak bertentangan dengan kaidah agama serta sesuai dengan umur pengguna koleksi. Misalnya saja, buku bertemakan ilmu pengetahuan dan teknologi. Hal ini bertujuan untuk menambah wawasan dari peserta didik di luar bidang agama. Selain koleksi buku, majalah terbitan berkala juga dapat dijadikan salah satu koleksi yang disimpan di perpustakaan.

Koleksi buku yang beragam ini perlu dijaga kondisinya agar tetap terawat. Hal-hal kecil yang penting dilakukan untuk merawat buku diantaranya:

1. Memberi sampul pada koleksi buku

2. Menyediakan pembatas halaman untuk menandai halaman terakhir yang dibaca

3. Meletakkan buku dalam keadaan berdiri pada rak khusus

4. Menyimpan buku di dalam lemari tertutup untuk menghindari debu

5. Menghindari menumpuk buku dengan jumlah yang banyak. Buku yang menerima beban terlalu besar di atasnya mengakibatkan lembaran-lembaran buku saling menempel. Selain itu, cetakan hurufnya menjadi cepat pudar.

6. Meletakkan butiran penyerap air (silica gel) dan kapur barus di dalam rak atau lemari buku

7. Tidak menjejalkan buku di dalam rak yang sudah penuh
8. Menghindari air, minyak, debu, dan panas matahari langsung atau lampu yang berkekuatan tinggi. Dikarenakan hal-hal tersebut dapat mengakibatkab kertas buku cepat berjamur, warnanya menguning dan mudah robek

Selain merawat koleksi buku perpustakaan, memelihara buku-buku yang menjadi koleksi juga sangat diperlukan. Beberapa hal yang bisa dilakukan dalam memelihara buku diantaranya:

1. Mencegah kerusakan

Untuk mencegah terjadinya kerusakan pada buku, hal utama yang harus diketahui yaitu faktor-faktor apa yang biasanya dapat merusak buku-buku, kemudian bagaimana cara mencegahnya sehingga buku-buku tidak mudah rusak.

2. Perbaikan buku

Usaha pencegahan seperti yang telah diuraikan di atas pada dasarnya merupakan usaha yang sifatnya preventif, dimana sebelum buku-buku rusak dilakukan usaha pencegahannya. Usaha-usaha perbaikan bukubuku bermacam-macam, bergantung kepada jenis kerusakannya. Biasanya yang sering dilakukan antara lain:

1) Memperbaiki buku-buku yang sedikit robek

2) Memperbaiki buku-buku yang sebagian halamannya lepas

3) Memperbaiki buku-buku yang punggungnya rusak

4) Menjilid buku-buku yang jilidnya lepas

Koleksi buku yang rusak harus segera diperbaiki, untuk menghindari bertambah besarnya biaya perbaikan. Beberapa hal dapat dilakukan untuk meminimalkan kerusakan koleksi buku yang disesuaikan dengan factor penyebab kerusakannya, seperti diuraikan berikut ini.

a. Kelembaban udara

Kelembaban yang ideal untuk bahan kertas adalah 40 - 50\%. Kelembaban di atas 65\% menyebabkan bahan pustaka capat rusak, sedangkan suhu udara yang tinggi dan lembab menyebabkan buku mudah ditumbuhi oleh jamur. Kelembaban udara dapat dikurangi dengan cara memberi ventilasi yang baik, memasang exhaustfan atau bila memungkinkan dapat dipasang AC.

b. Sinar matahari

Buku yang terkena sinar matahari langsung menyebabkan tulisannya mudah rusak atau hilang. Untuk itu penataan rak buku harus menghindari paparan sinar matahari.

c. Hewan/ serangga

Beberapa hewan yang dapat menyebabkan kerusakan buku diantaranya kecoa, ngengat, dan hewan pengerat seperti tikus. Untuk menghindari munculnya hewan-hewan tersebut, kebersihan ruangan harus tetap dijaga. Tindakan ini lebih baik jika dibandingkan dengan menggunakan insektisida dalam membunuh hewan-hewan tersebut, mengingat insektisida dimungkinkan dapat membahayakan 
manusia jika digunakan terlalu sering dan dalam jangka waktu yang lama.

d. Manusia

Manusia yang kurang bertanggung jawab tidak hanya dapat menyebabkan kerusakan, namun juga dapat menghilangkan koleksi buku. Penjagaan yang ketat perlu dilakukan terhadap hal tersebut, dan memberikan sanksi bagi yang melakukannya.

Selain beberapa hal yang sudah disebutkan di atas, beberapa hal yang juga perlu dilakukan terkait pemeliharaan dan perawatan koleksi buku perpustakaan adalah:

1. Reproduksi

Bahan pustaka yang langka dan harus dilestarikan perlu dibuatkan salinan. Pustaka aslinya disimpan, sementara yang dipinjamkan adalah salinan. Pustaka juga dapat dilestarikan dalam bentuk soft copy. Apabila telah dibuat bentuk ini, sebaiknya masternya disimpan dan yang disajikan untuk dibaca atau dipinjam hanya salinannya.

2. Penjilidan

Koleksi yang ada di perpustakaan perlu dilakukan penjilidan. Penjilidan beberapa koleksi sejenis dalam beberapa volume didasarkan pada nomor, yaitu diurut dari nomor terkecil sampai nomor terbesar. Identitas buku yang sedang dijilid atau diperbaiki dicatat dengan jelas dan teliti, sehingga apabila ada yang ingin menggunakannya dapat diberi informasi yang betul. Penjilidan ini dapat dilakukan seperti pada koleksi:

1) Majalah yang sudah lengkap satu volume atau satu tahun agar tidak berserakan sehingga mudah rusak atau hilang

2) Buku - buku yang jilidnya rusak dan masih mungkin untuk dijilid ulang, sehingga tetap dapat dimanfaatkan

3. Laminasi

Koleksi lama yang kertasnya sudah lapuk sehingga mudah hancur jika terlalu sering digunakan, dapat diawetkan dengan menyemprotkan bahan kimia atau dilaminasi.

4. Penyiangan

Koleksi perpustakaan yang terus berkembang akan selalu bertambah namun hal ini tidak selalu diikuti oleh penambahan ruang. Kemampuan ruang untuk menampung koleksi selalu terbatas, sehingga pustakawan harus mencari jalan keluar agar tambahan koleksi selalu dapat tertampung. Pemecahan permasalahan ini adalah mengurangi koleksi lama dengan cara mengadakan penyiangan koleksi. Pustaka yang disiang adalah :

1. Buku yang umurnya sudah tua, isinya sudah kadaluwarsa dan tidak cocok lagi untuk dibaca

2. Buku yang rusak dan tidak mungkin diperbaiki lagi

3. Buku yang jumlah kopinya terlalu banyak

4. Buku yang tidak sesuai

\subsection{Sistem Peminjaman}

Sistem peminjaman buku yang paling sesuai untuk dilakukan adalah sistem slip. Untuk itu, setiap koleksi buku harus dilenkapi dengan slip yang diletakkan pada kantong di sampul buku bagian belakang. Slip ini nantinya berisi data tentang nama peminjam dan tanggal pengembalian. Setiap kali buku tersebut dipinjam, maka slip harus diambil dan disimpan dalam meja peminjaman. Pencatatan dalam slip ini bisa dilakukan oleh asisten pustakawan. Apabila terjadi keterlambatan dalam pengembalian buku, maka asisten pustakawan berhak untuk menanyakan kepada peminjam yang namanya tertera pada slip. Peminjaman koleksi buku juga perlu dibuat peraturan tambahan, diantaranya hari dan jam peminjaman, jumlah buku yang boleh dipinjam, lama peminjaman dan sanksi yang diberikan apabila ada pelanggaran. Ketentuan lain dalam peminjaman buku seperti koleksi buku yang dipinjam harus kembali dalam kondisi baik, apabila saat pengembalian rusak maka peminjam yang dalam hal ini adalah peserta didik bersedia untuk memperbaikinya.

\subsection{Anggaran}

Anggaran merupakan salah satu unsur penunjang perpustakaan agar keberlangsungan kegiatan di perpustakaan tetap berjalan. Dengan belum adanya bantuan dana dari pemerintah yang diberikan secara rutin kepada madrasah diniah untuk pengembangan perpustakaan, maka disarankan anggaran ini diambilkan dari sebagian dana iuran dari peserta didik. Anggaran ini utamanya untuk perawatan koleksi buku dan pengadaan untuk menambah koleksi perpustakaan. Dengan keterbatasan dana yang dimiliki, dua kegiatan tersebut dapat dilakukan setiap satu atau dua tahun sekali.

Di dalam penggunaan anggaran perpustakaan seharusnya memang sebagian digunakan untuk membayar honor pengelola perpustakaan. Mengingat tugas seorang pustakawan pada perpustakaan madrasah diniah ini dirangkap oleh tenaga pendidik madrasah diniah sendiri dan tugas pustakawan dilakukan dalam jangka waktu yang kurang dari lima jam per minggu, maka honor pustakawan dibebankan pada anggaran madrasah diniah. Sehingga seluruh anggaran untuk perpustakaan dikhususkan untuk perawatan dan pengadaan koleksi perpustakaan.

\subsection{Pengadaan Meja}

Meja lipat kecil berbahan dasar kayu sesuai untuk meja lipat yang dapat digunakan oleh peserta didik. Bahan kayu yang dipilih adalah kayu dengan kualitas cukup bagus namun memiliki harga yang tidak relatif mahal. Selain itu, pemilihan berat akhir dari meja harus cukup ringan. Mengingat meja lipat ini nantinya 
akan dibawa oleh peserta didik pada saat melakukan kegiatan di luar madrasah.

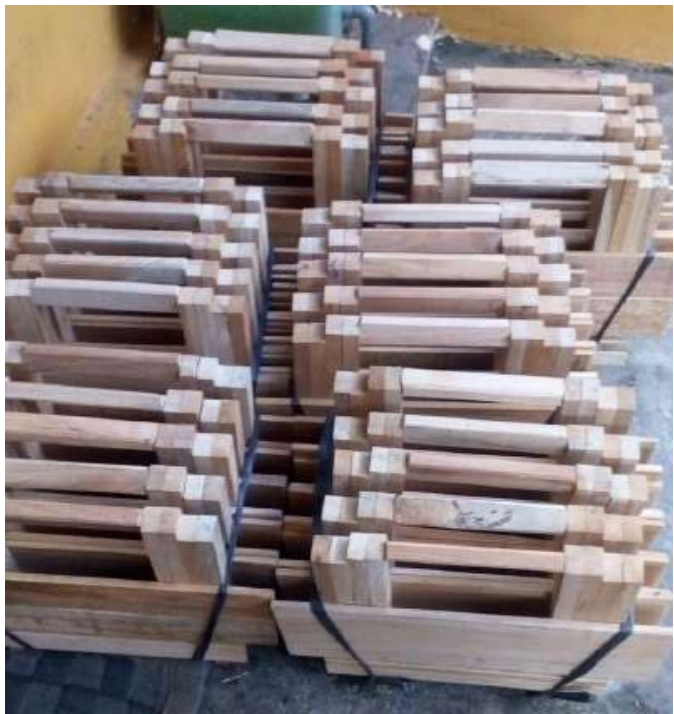

Gambar 1. Meja lipat sebelum dicat

Kondisi meja lipat yang belum dicat sudah dapat digunakan, namun dari segi penampilan kurang menarik. Selain itu masuh ada beberapa bagian meja yang cukup tajam, yang dapat dimungkinkan kurang rapinya pada saat penyelesaian pembuatan meja. Hal ini cukup berbahaya bagi peserta didik, mengingat meja ini akan dimobilisasi cukup sering oleh peserta didik. Untuk memperindah tampilan dan mengurangi ketajaman dari meja, maka perlu dilakukan pengecatan pada meja.

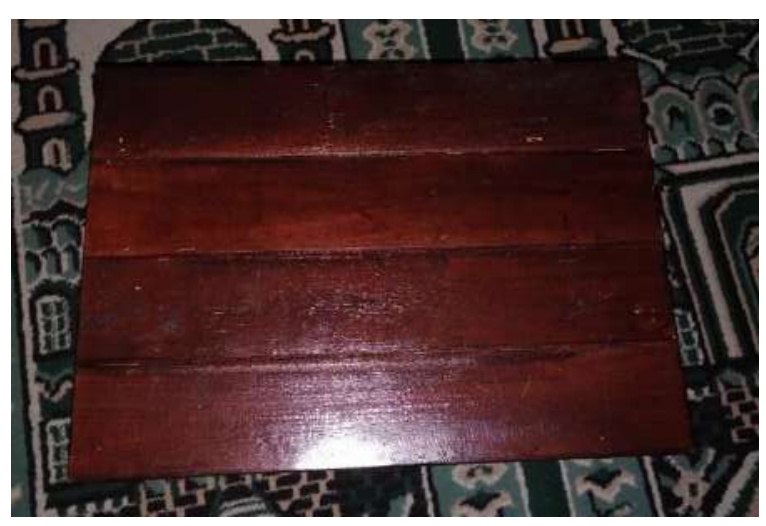

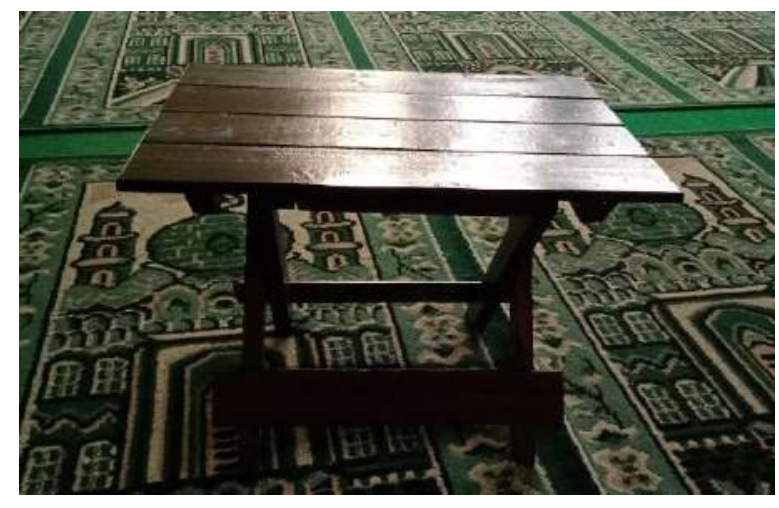

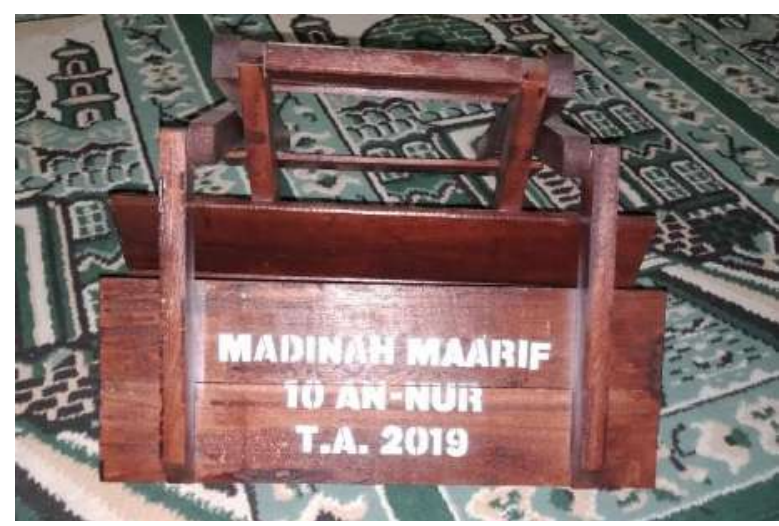

Gambar 2. Meja lipat sesudah dicat
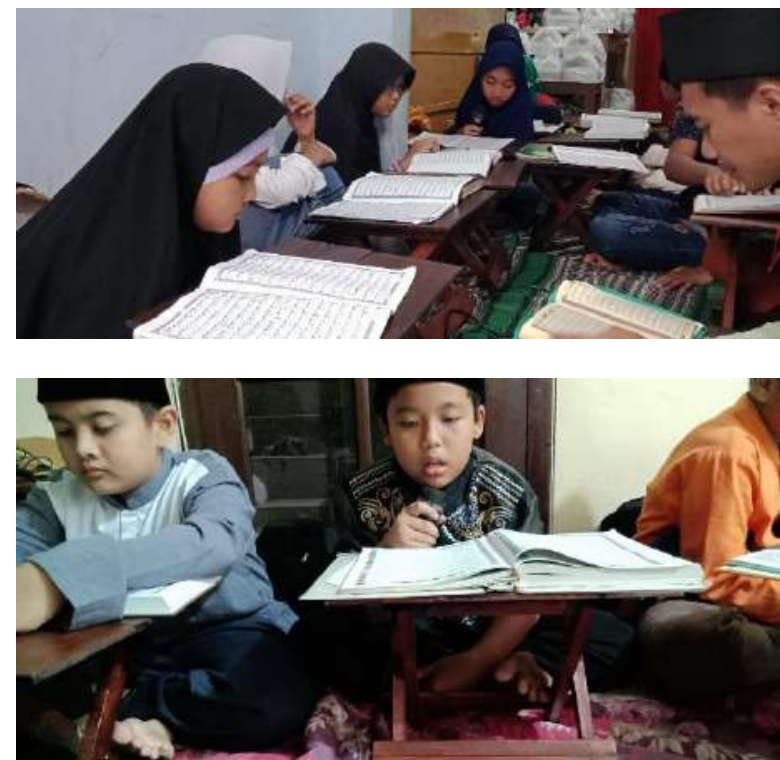

Gambar 3. Penggunaan meja oleh peserta didik pada saat kegiatan di luar madrasah

\section{KESIMPULAN}

1. Pada pengelolaan perpustakaan perlu dilakukan oleh pustakawan dan asisten pustakawan. Kedua posisi tersebut dapat dilakukan oleh tenaga pendidik madrasah dibantu peserta didik yang senior. 
2. Konsep pelayanan perpustakaan adalah kombinasi sistem pelayanan tertutup dan terbuka.

3. Pengawasan terhadap perpustakaan dilakukan langsung oleh ketua madrasah diniah.

4. Koleksi buku diutamakan yang berkaitan dengan kurikulum pendidikan di madrasah dan ditunjang dengan buku lainnya yang dapat menambah wawasan peserta didik.

5. Sisitem peminjaman buku menggunakan metode slip.

6. Anggaran penyelenggaraan perpustakaan diambilkan dari dana yang dipungut dari peserta didik.

7. Meja lipat yang digunakan adalah berbahan dasar kayu namun memiliki berat yang cukup ringan agar dapat dengan mudah dibawa dan dipindahkan oleh peserta didik.

\section{DAFTAR PUSTAKA}

[1]. Anonim. (2015, Mei). Guru Pantura. Retrieved from Pengertian dan Contoh Pendidikan Formal, Nonformal dan Informal:
[2]. Kurniawan, Y. (2011). Pengelolaan Perpustakaan di Sekolah Menengah Pertama Negeri 1 Sentolo Kabupaten Kulon Progo. Yogyakarta: Universitas Negeri Yogyakarta.

[3]. Lamudi. (2014, Juni 5). Retrieved Oktober 25, 2018, from Jenis Kayu Untuk Furniture: https://www.lamudi.co.id/journal/jenis-kayuuntuk-furniture/

[4]. Mangapeng, R. E. (2016). Peranan Pengelola Perpustakaan dalam Meningkatkan Pelayanan Bagi Siswa SMP Negeri Empat Manado. $e$ journal "Acta Diurna" Volume V No. 3.

[5]. Meliyakin, E. (2013, Juni 21). Retrieved from Jalur, Jenjang, dan Jenis Pendidikan: https://ekameliyakin.wordpress.com/2013/06/26/j alur-jenjang-dan-jenis-pendidikan/

[6]. wan/tau/jun/byu. (2017, Agustus 11). jpnn.com. Retrieved from Fakta! Dampak Sekolah 5 Hari, Siswa Madin dan Pesantren Berkurang Drastis: https://www.jpnn.com/kementan/news/faktadampak-sekolah-5-hari-siswa-madin-danpesantren-berkurang-drastis 